Article

\title{
Ocean-Atmosphere Interactions during Hurricanes Marco and Laura (2020)
}

\author{
Emily N. Eley ${ }^{1, *(\mathbb{D}}$, Bulusu Subrahmanyam ${ }^{1}(\mathbb{D})$ and Corinne B. Trott $^{2} \mathbb{D}$ \\ 1 School of the Earth, Ocean and Environment, University of South Carolina, Columbia, SC 29208, USA; \\ sbulusu@geol.sc.edu \\ 2 Naval Research Laboratory, Stennis Space Center, Mississippi, MS 39529, USA; corinne.trott@nrlssc.navy.mil \\ * Correspondence: eeley@seoe.sc.edu
}

check for updates

Citation: Eley, E.N.; Subrahmanyam, B.; Trott, C.B. Ocean-Atmosphere Interactions during Hurricanes Marco and Laura (2020). Remote Sens. 2021, 13, 1932. https://doi.org/10.3390/ rs13101932

Academic Editors: Meer Mohammed Ali and Mark Bourassa

Received: 17 April 2021

Accepted: 12 May 2021

Published: 15 May 2021

Publisher's Note: MDPI stays neutral with regard to jurisdictional claims in published maps and institutional affiliations.

Copyright: (C) 2021 by the authors. Licensee MDPI, Basel, Switzerland. This article is an open access article distributed under the terms and conditions of the Creative Commons Attribution (CC BY) license (https:/ / creativecommons.org/licenses/by/ $4.0 /)$.

\begin{abstract}
During August of the 2020 Atlantic Hurricane Season, the Gulf of Mexico (GoM) was affected by two subsequent storms, Hurricanes Marco and Laura. Hurricane Marco entered the GoM first (22 August) and was briefly promoted to a Category 1 storm. Hurricane Laura followed Marco closely (25 August) and attained Category 4 status after a period of rapid intensification. Typically, hurricanes do not form this close together; this study aims to explain the existence of both hurricanes through the analysis of air-sea fluxes, local thermodynamics, and upper-level circulation. The GoM and its quality of warm, high ocean heat content waters proved to be a resilient and powerful reservoir of heat and moisture fuel for both hurricanes; however, an area of lower ocean heat content due to circulation dynamics was crucial in the evolution of both Marco and Laura. An analysis of wind shear further explained the evolution of both hurricanes. Furthermore, a suite of satellite observations and ocean model outputs were used to evaluate the biophysical modulations in the GoM. The cold core eddy (CCE) and Mississippi River surface plume had the greatest biophysical oceanic responses; the oceanic modulations were initialized by Marco and extended temporally and spatially by Laura. Reduced sea surface temperatures (SST), changes in sea surface salinity (SSS), and changes in Chlorophyll-a (Chl-a) concentrations are related to translation speeds, and respective contributions of hurricane winds and precipitation are evaluated in this work.
\end{abstract}

Keywords: Hurricane Laura (2020); Hurricane Marco (2020); Gulf of Mexico; eddies; salinity; SMAP

\section{Introduction}

The Gulf of Mexico (GoM) is a semi-enclosed Atlantic basin and a prime region for the formation, maintenance, and intensification of tropical cyclones due to its high ocean heat content $(\mathrm{OHC})$ [1-3]. The permanently stratified, oligotrophic, relatively warm water column enables the rapid rebound of the GoM's high sea surface temperatures (SSTs) after the passage of a hurricane, fueling conditions favorable for the formation of consecutive storms [4]. This SST recovery was exhibited in 2005 with the passage of Hurricanes Katrina and Rita [1-5]. Again in 2017, Hurricanes Harvey and Irma, two Category 4 hurricanes upon landfall, traversed the GoM within a two-week time frame [6,7]. A similar phenomenon was observed during the 2020 Atlantic hurricane season with the subsequent passing of Hurricanes Marco and Laura across the GoM basin.

The formation, intensification, and weakening of tropical cyclones directly relate to local ocean dynamics. OHC provides the energy necessary for deep atmospheric convection via heat and moisture fluxes to the atmosphere and is directly dependent upon the mixed layer depth (MLD) [8,9]. The Loop Current (LC) and associated Loop Current eddies (LCEs) are the dominant circulation and thermodynamic features in the GoM [10]. The LC carries high-OHC waters from the Caribbean into the basin through the Yucatán Channel and out through the Florida Straits to rejoin the Gulf Stream [11]. LCEs develop at irregular intervals and are products of the LC; eddy shedding includes larger warm core eddies (anticyclonic) (WCEs) and smaller cold core eddies (CCEs) (cyclonic) [12,13]. 
Hurricanes typically require SST greater than $26^{\circ} \mathrm{C}$ and OHC greater than $6.0 \times 10^{-8} \mathrm{~J} \mathrm{~m}^{-2}$ for successful formation and maintenance $[8,14,15]$. The LC and associated warm, anticyclonic mesoscale eddies' capability to act as heat reservoirs and enhance surface enthalpy fluxes make it an essential component for GoM hurricane studies. Interactions between tropical cyclones and the LC and associated eddies have been abundantly studied in the GoM $[1,5,16,17]$. Studies show that hurricanes undergo periods of intensification when passing over the LC or WCE, gaining energy from the warm waters with typical OHC values $>10.0 \times 10^{-8} \mathrm{~J} \mathrm{~m}^{-2}$ [8]; oppositely, storms weaken when passing over a CCE due to lower heat content $[17,18]$. Additionally, LCEs modulate the biophysical response of the upper ocean to the passage of a storm due to their preexisting cyclonic or anticyclonic rotations that induce eddy pumping [19] and modulate the underlying mixed layer [20].

The GoM's 2020 hurricane season experienced consecutive storms with the passing of Hurricanes Marco (20-25 August 2020) and Laura (20-28 August 2020) [21,22] (NOAA NHC, Atlantic Current Season Summary, 2020). Nearly two days following Marco's peak intensity, Laura entered the GoM through the Yucatán Channel before undergoing a period of rapid intensification seemingly unaffected by Marco's prior presence (NOAA NHC Advisory Archive, 2020). Hurricane Laura was the earliest hurricane of the $2020 \mathrm{GoM}$ hurricane season that attained Category 4 status, with maximum sustained winds of $150 \mathrm{mph}$ and minimum pressure of $939 \mathrm{hPa}$ and holds the Louisiana record for greatest sustained winds at landfall of $145 \mathrm{mph}$ [21-23] (NOAA NHC, Atlantic Current Season Summary, 2020). Marco was promoted to a Category 1 hurricane for a short duration, with maximum sustained winds of $75 \mathrm{mph}$ and minimum pressure of $991 \mathrm{hPa}$ (NOAA NHC, Atlantic Current Season Summary, 2020). A study conducted by Jafari et al. (2020) describes the use of collected Hurricane Laura data evaluating both natural and hard infrastructure hurricane-response; they reported a $0.5 \mathrm{~m}$ loss of elevation on the sand beach and a storm surge of 3-4 m [24]. Additionally, Hurricane Laura was used in a case study evaluating the Global Navigation Satellite System's (GNSS) usefulness in acquiring near real time data on sea level variations [25]. There is minimal literature on the air-sea interactions and biophysical impacts of both Marco and Laura in the GoM.

In this study, we investigate the temporally consecutive and spatially adjacent Hurricane Marco and Hurricane Laura (August 2020), and the combined biophysical responses of the surface and modeled sub-surface GoM basin using satellite data and numerical models. We analyze sea level pressure (SLP), heat and moisture fluxes, LC dynamics, and environmental wind shear to understand the interplay between these two storms. SST, sea surface salinity (SSS), and chlorophyll-a (Chl-a) concentrations are examined to ascertain the biophysical state of the GoM before, during and after the passage of the tropical cyclones. Additional parameters are observed to compare each storm, including precipitation, outgoing longwave radiation (OLR), vorticity and winds. A numerical ocean model was utilized to study the temperature and salinity changes throughout the water column in the wake of both cyclones. Since little time has passed since the occurrence of Hurricanes Marco and Laura, limited research has been executed investigating the air-sea interactions of the two storms and the response of the upper ocean basin to these combined storms. This paper examines the unusual occurrence of paired tropical cyclones during the GoM's 2020 hurricane season. The remaining sections are organized as follows: Section 2 summarizes the data and methodology used, Section 3 discusses the results of this research, and Section 4 further discusses the reported results and conclusions.

\section{Materials and Methods}

2.1. Data

\subsubsection{Satellite Observations}

Best track data are obtained from the National Oceanic and Atmospheric Association's (NOAA's) National Hurricane Center's (NHC's) Hurricane Marco Advisory Archive and Hurricane Laura Advisory Archive (https:/ /www.nhc.noaa.gov/archive/2020/MARCO. shtml, https:/ / www.nhc.noaa.gov / archive/2020/LAURA.shtml) (accessed on 13 Novem- 
ber 2020). Four time points (03:00 UTC, 09:00 UTC, 15:00 UTC, 21:00 UTC) for each day an advisory existed are used for plotting each storm track. The reported latitude, longitude, minimum central pressures, and maximum sustained wind speeds are used to identify the storms' positions and evolution (Figure 1).
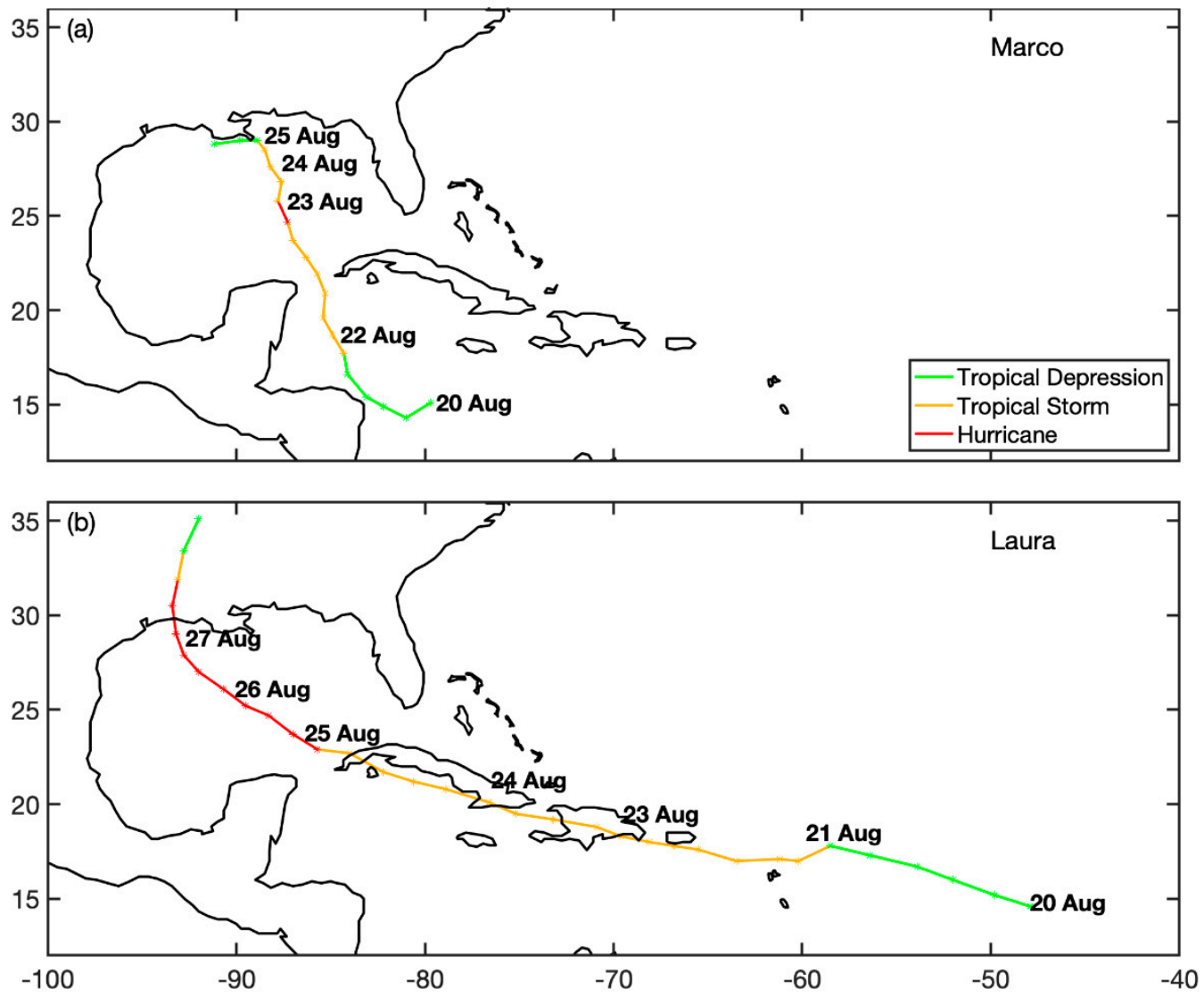

Figure 1. The tracks and evolutions of Hurricane Marco (a) and Hurricane Laura (b) as reported by the National Hurricane Center's hurricane advisory archive during 2020.

Surface wind fields are accessed through Remote Sensing Systems (RSS; remss.com/ missions/ascat) and are retrieved from the Advanced Scatterometer (ASCAT). Version 2.1 is used in the analysis of winds due to its improved wind retrieval in rainy conditions and higher quality bias controls [26]. ASCAT winds are deemed appropriate for tropical storms where winds and rainfall are high $[26,27]$. The daily and 3-day wind files have a spatial resolution of $0.25^{\circ}$. ASCAT observes the Earth daily at approximately 9:30 a.m./p.m. local time [27]. Furthermore, also obtained from RSS, Cross-Calibrated Multi-Platform (CCMP) version 2.0 daily surface winds are used to evaluate hurricane winds. The CCMP dataset is a wind analysis product that uses 6 different hourly ocean wind vectors and has a daily spatial resolution of $0.25^{\circ}$.

SST is analyzed using the optimum interpolation sea surface temperature (OISST) Version 2 [28]. The OISST uses SST data from the advanced very high-resolution radiometer (AVHRR) and additional in situ data [28] and is exported from NOAA's National Center for Environmental Information (NCEI). OISST has a spatial resolution of $0.25^{\circ}$ and is available from 1978 to the present at daily temporal resolution.

SSS is processed and issued by the National Aeronautics and Space Association's (NASA) Jet Propulsion Laboratory (JPL), and retrieved from the Soil Moisture Active Passive (SMAP) mission. When compared with its predecessor Aquarius/SAC-D, SMAP has a larger swath coverage of $1000 \mathrm{~km}$ and improved bias corrections. The spatial resolution of 
SMAP is $0.25^{\circ}[29,30]$. We use the most recent version (5.0) with corrections to brightness temperature biases and bias correction between ascending and descending passes [30].

Instantaneous moisture flux, surface latent heat flux, SLP and $200 \mathrm{mb}$ and $850 \mathrm{mb}$ upper-level zonal and meridional winds are provided by the European Centre for MediumRange Weather Forecast's (ECMWF; https: / / www.ecmwf.int/en/forecasts/datasets, accessed on 11 January 2021) ERA5 global reanalysis datasets that are produced by the Copernicus Climate Change Service (C3S). ERA5 is available from 1950 to the present (though we only use 2020 in this study) and is produced using ECMWF's Integrated Forecast System (IFS) Cy41r2 (2016) with 137 vertical model levels, and has a spatial resolution of $0.25^{\circ}$ [31,32]. As of August 2019, ERA5 replaced the ERA-Interim reanalysis with heightened spatial and temporal resolutions, improvements in atmospheric parameters, and most importantly for this study, improved consideration of tropical cyclones [31,32]. Instantaneous moisture flux represents evaporation as an upward flux from the ocean surface to the atmosphere (negative values) and condensation as a downward flux from the atmosphere to the ocean surface (positive values) [33].

Chl-a concentration is derived from daily, gap-filled Visible Infrared Imagining Radiometer Suite (VIIRS) onboard the Suomi National Polar-orbiting Partnership (SNPP) plus NOAA-20 [34]. The data are downloaded from NOAA's CoastWatch data portal ( https: / / coastwatch.noaa.gov / cw_html/cwViewer.html, accessed on 14 May 2021) to investigate the biological impacts of Hurricanes Marco and Laura on the upper ocean [35]. This product has a spatial resolution of $9 \mathrm{~km}$. The Data Interpolating Empirical Orthogonal Functions (DINEOF) method for gap-filled analysis is described in Liu and Wang (2018), and Beckers and Rixen (2003) [34,36].

Daily and 30-min precipitation data are obtained from the joint NASA and Japan Aerospace Exploration Agency (JAXA) Global Precipitation Measurement (GPM) mission. The merged constellation GPM product is available from 2014 to the present in near real time at $0.1^{\circ}$ gridded resolution. Data are obtained from NASA's Earthdata database archive (https:/ / pmm.nasa.gov/data-access/downloads/gpm, accessed on 13 January 2021).

OLR is obtained from NOAA's Physical Research Laboratory (PSL), which retrieves data directly from NOAA's National Center for Environmental Prediction (NCEP). The daily mean, non-interpolated OLR product has a gridded spatial resolution of $2.5^{\circ}$. Sea level anomalies (SLA) are obtained from Copernicus Marine and Environmental Monitoring Service (CMEMS; marine.copernicus.eu), produced from daily blended altimetric observations originally developed by AVISO+ (Archiving, Validation, and Investigation of Satellite Oceanography). Daily SLA data have a spatial resolution of $0.25^{\circ}$ and compile all altimeter mission observations into one daily product [37].

\subsubsection{Ocean Models}

Ocean MLD, barrier layer thickness (BLT), isothermal layer depth (ILD), and OHC are from a high-resolution ocean model, the Nucleus for European Modeling of the Ocean (NEMO) version 3.4 (NEMOv3.4) [38]. These parameters are calculated using a density criterion of $0.03 \mathrm{~kg} \mathrm{~m}^{-3}$ to remain consistent with other studies in the central tropical Atlantic [39,40]. NEMO output is available from 2016 to the present as 10-day forecasts at $1 / 12^{\circ}$ horizontal spatial gridding and 50 vertically stratified depths. The ocean model is utilized to visualize the MLD and ILD; the area between the two layers is termed the BLT.

\subsection{Methodology}

Environmental vertical wind shear is calculated using the $200 \mathrm{hPa}$ and $850 \mathrm{hPa}$ upperair winds following the methods employed in DeMaria et al. (2005), Emanuel et al. (2004), and Zehr (2003) [14,41,42]. Environmental wind shear is spatially averaged over each hurricane at their greatest intensities. Due to the symmetry of tropical cyclone circulation, the cyclone shear tends to be cancelled out and the environmental wind profile remains [42]. The shear is a difference calculation of wind vectors that is then averaged over $23-27^{\circ} \mathrm{N}$ latitude and 87-93 ${ }^{\circ} \mathrm{W}$ longitude from 13-31 August 2020. 


\section{Results}

\subsection{Storm Analysis}

Marco (Figure 1a) entered the GoM on 22 August and traversed the basin for three days before landfalling near the mouth of the Mississippi River (MS River); Marco briefly surpassed the threshold for Category 1 status from 23 August 16:00 UTC until 24 August 1:00 UTC with maximum sustained winds of $75 \mathrm{mph}$ according to the NHC hurricane advisory archive. Marco traversed the basin meridionally between latitudes $85^{\circ} \mathrm{W}$ and $90^{\circ} \mathrm{W}$; Laura's path (Figure 1b) was more westward-oriented over the basin, intersecting Marco's track once at approximately $85^{\circ} \mathrm{W}$ and $25^{\circ} \mathrm{N}$. Hurricane Laura made landfall once over the Island of Hispaniola and twice over Cuba before it entered the GoM over the Yucatán Channel on 25 August. Laura experienced a period of rapid intensification after meeting the GoM's warm, high OHC waters; the storm explosively upgraded from a Category 1 to a Category 4 storm within the time frame of 25 August 10:00 UTC to 26 August 13:00 UTC. Laura maintained strong winds; the NHC reported maximum sustained winds of $150 \mathrm{mph}$ and a reduction to $145 \mathrm{mph}$ winds before landfalling near Cameron, Louisiana on 27 August 1:00 UTC.

The hurricane translation speeds vary between storms and are calculated using hurricane track data; translation speeds have direct implications for the magnitude and region of hurricane-forced biophysical modulations. Marco's average translation speed over the entire track shown in Figure $1 \mathrm{a}$ is $5.81 \mathrm{~m} \mathrm{~s}^{-1}$, while Laura's is $8.58 \mathrm{~m} \mathrm{~s}^{-1}$ over the entire track shown in Figure 1b. The average translation speeds during the extent of time Marco and Laura were classified as hurricanes are $5.67 \mathrm{~m} \mathrm{~s}^{-1}$ and $7.02 \mathrm{~m} \mathrm{~s}^{-1}$, respectively.

The size of each storm can be visualized through vorticity, SLP and OLR (Figure 2). Each parameter is plotted for the day of greatest intensity for each storm (Marco, 24 August; Laura, 26 August). Marco's vorticity distribution is extremely centralized about $26^{\circ} \mathrm{N}$ and $87^{\circ} \mathrm{W}$ and is isolated with little reach to surrounding regions (Figure 2a). Laura's greatest vorticity is centralized around $25^{\circ} \mathrm{N}$ and $88^{\circ} \mathrm{W}$ and impacts the atmospheric rotational behavior far from the storm center relative to Marco's reach (Figure 2b). Marco's underdeveloped atmospheric convection is evident when compared to Laura's distinct organized cyclonic directional wind vectors (Figure $2 \mathrm{a}, \mathrm{b}$; Figure $3 \mathrm{a}, \mathrm{b}$ ). Laura is clearly a more expansive and more powerful storm than Marco when comparing SLPs. Marco is included in a broad dome of lower pressure when the ERA-5 reanalysis is observed, and Laura is shown as an independent low-pressure system in the southwest basin (Figure 2c,d). ERA-5 data in Figure 2c,d report Marco's minimum pressure to be included in the $1002 \mathrm{hPa}$ region of lower pressure and Laura's minimum pressure as $998 \mathrm{hPa}$. Hurricane Marco is not shown as an isolated low-pressure system due to it being a daily average and the quick translation of the hurricane across the basin (Figure 2c). The discrepancy between the vorticity and SLP storm signatures of Hurricane Laura is attributed to the high pressure pushing westward into the basin from the northeast region of the spatial map (Figure 2d). OLR, representative of cloud cover, slightly leads the signal of SLP and vorticity and provides another view of the individual magnitudes of both storms at their peak intensities (Figure 2e,f). The leading edge of Laura's cloud cover is visible at the mouth of the GoM basin while Marco's cloud cover signal is over land, consistent with the archived locations of the storms (Figure 2e). The difference in Marco's position between SLP and OLR is attributed to the difference in satellite passes, thus a difference in daily averages especially when the storm is moving so quickly (Figure 2a,e). 

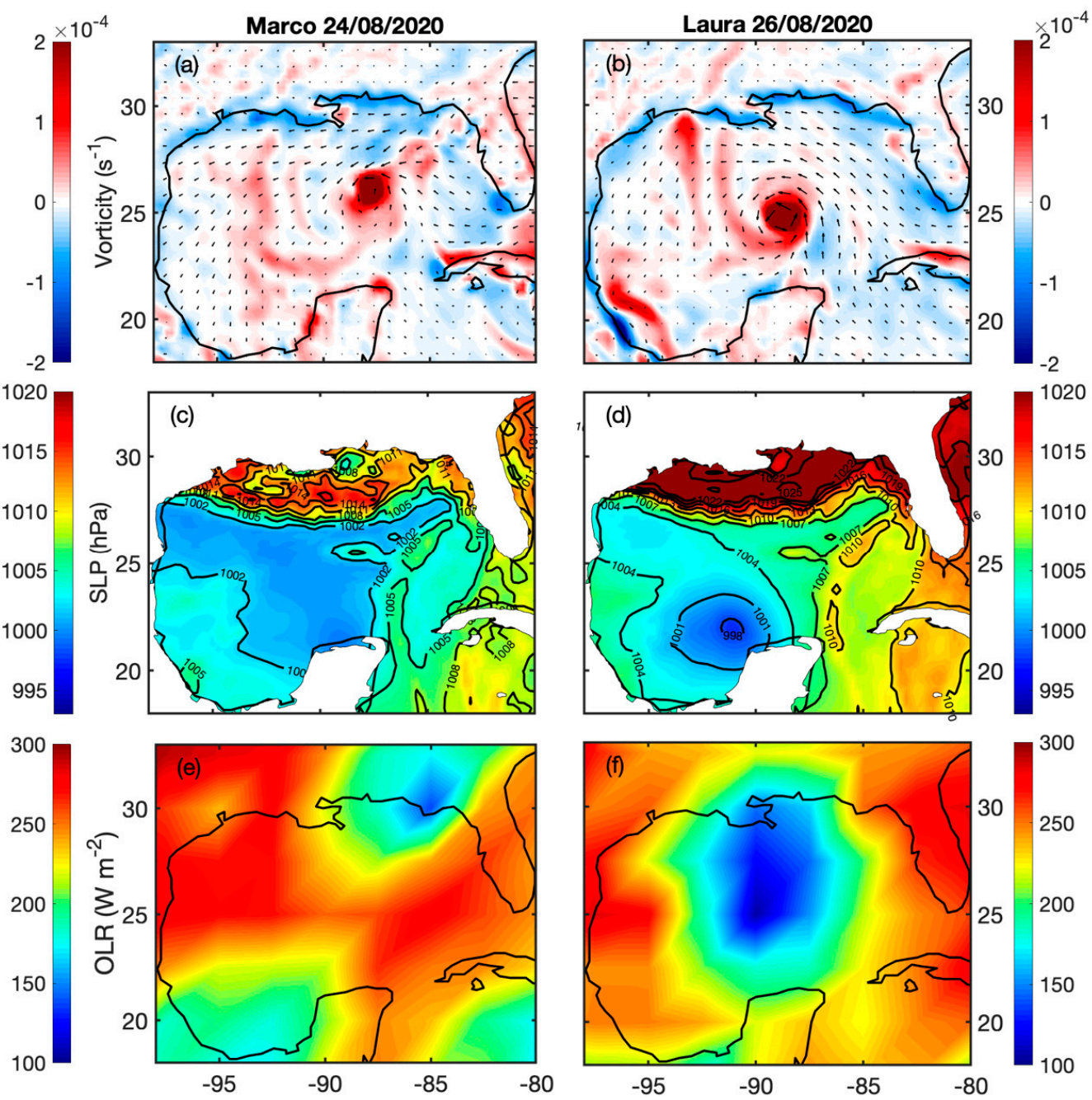

Figure 2. (a,b) Vorticity $\left(\mathrm{s}^{-1}\right)$ derived from CCMPv2.0 reanalysis winds $\left(\mathrm{m} \mathrm{s}^{-1}\right),(\mathbf{c}, \mathbf{d})$ sea level pressure (SLP; $\mathrm{hPa})$, and $(\mathbf{e}, \mathbf{f})$ outgoing longwave radiation $\left(\mathrm{OLR} ; \mathrm{W} \mathrm{m}^{-2}\right.$ ) conditions of near-peak intensities for both Marco (24 August 2020) and Laura (26 August 2020). SLP contours are every $3 \mathrm{hPa}$.

ASCAT daily winds and daily GPM precipitation are plotted for the day of greatest intensity for each respective storm (Figure 3). During Marco's peak intensity, Laura is positioned over Cuba (Figure 3a,c). Laura's wind speed and rainfall measurements over Cuba are greater than Marco's recorded parameters (Figure 3a,c), indicating that Laura gained significant moisture and heat energy prior to entering the GoM. Two days following Marco's peak intensity, Laura has deeply organized cyclonic wind directions with magnitudes exceeding $20 \mathrm{~m} \mathrm{~s}^{-1}$ (Figure $3 \mathrm{~b}$ ), and expansive precipitation coverage with values greater than $150 \mathrm{~mm} \mathrm{day}^{-1}$ in the central GoM (Figure 3d). Precipitation leads the hurricane winds for both storms at daily resolution (Figure 3). 

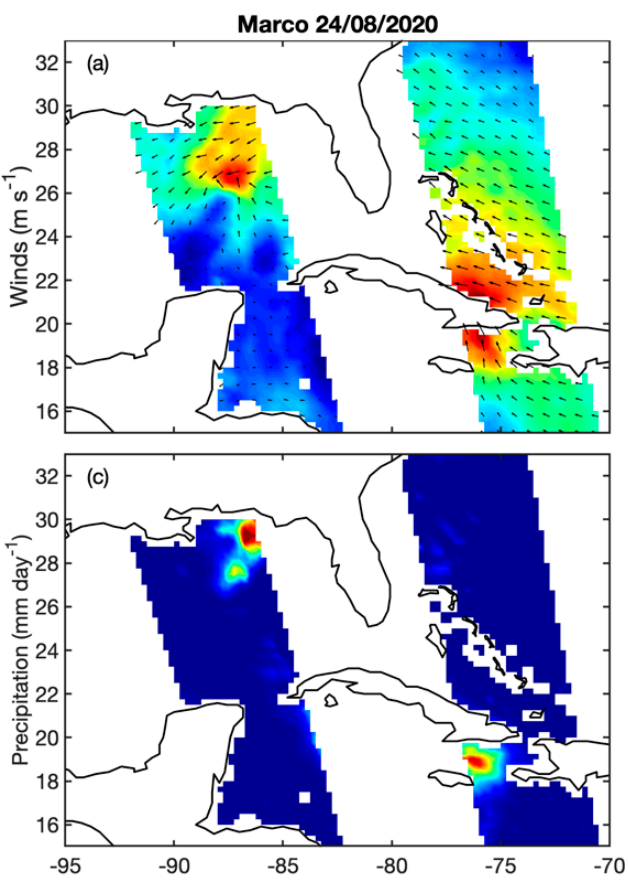
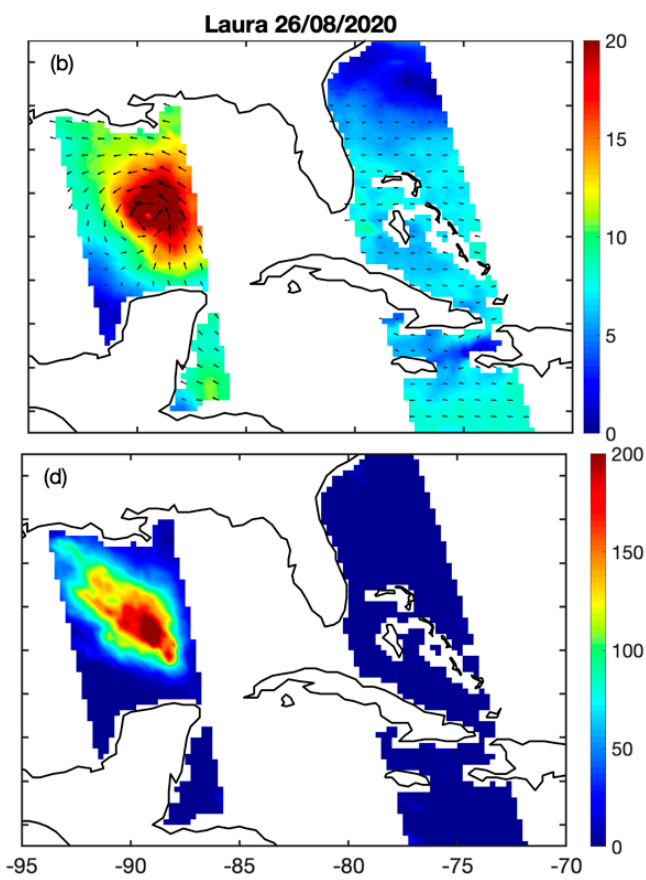

Figure 3. (a,b) Advanced scatterometer (ASCAT) daily winds $\left(\mathrm{m} \mathrm{s}^{-1}\right)$, and (c,d) global precipitation measurement (GPM; mm/day) conditions of near-peak intensities for both Marco (24 August 2020) and Laura (26 August 2020) along daily descending swath coverage of the ASCAT mission.

Hourly GPM precipitation measurements and moisture flux reflect nearly identical positions for each cyclone (Figure 4). On 23 August 12:00, Marco causes a loss of moisture from the sea surface into the atmosphere with maximum negative fluxes of $-15 \times 10^{-5}$ to $-18 \times 10^{-5} \mathrm{~kg} \mathrm{~m}^{-2} \mathrm{~s}^{-1}$ (Figure 4a); a corresponding GPM precipitation measurement of $10-20 \mathrm{~mm} \mathrm{hr}^{-1}$ with a maximum value of $84 \mathrm{~mm} \mathrm{hr}^{-1}$ is observed over the central storm (Figure 4b). On 24 August, Marco's position is shown as heightened negative moisture flux values near the MS River delta, and Laura is seen as a patch of negative moisture flux between Cuba and Florida (Figure 4c) and as rainfall moving towards the GoM basin (Figure 4d). Moisture flux values increase in absolute value to $0 \mathrm{~kg} \mathrm{~m}^{-2} \mathrm{~s}^{-1}$ to $2.5 \times 10^{-5} \mathrm{~kg} \mathrm{~m}^{-2} \mathrm{~s}^{-1}$ prior to Laura's journey over the GoM (Figure 4c). No storm other than Marco impacted the maintenance and intensification of Laura within the GoM. Laura was most intense on 26 August 12:00 when observing GPM and moisture flux (Figure 4e,f); for both parameters, the position of the hurricane is consistent, and deep organized convection is prevalent. A structured hurricane eye at $26^{\circ} \mathrm{N}$ and $92^{\circ} \mathrm{W}$ is observed via negative moisture flux values; the eye collects little moisture when compared to its outer wall (Figure 4e). Laura's rainfall covers an expansive area of the basin in comparison to Marco, with rainfall measurements from $5 \mathrm{~mm} \mathrm{hr}^{-1}$ at the storm edges and typical values of $10-15 \mathrm{~mm} \mathrm{hr}^{-1}$; there is a maximum value of $92 \mathrm{~mm} \mathrm{hr}^{-1}$ at the southernmost reach of the storm (Figure $4 \mathrm{f}$ ). 

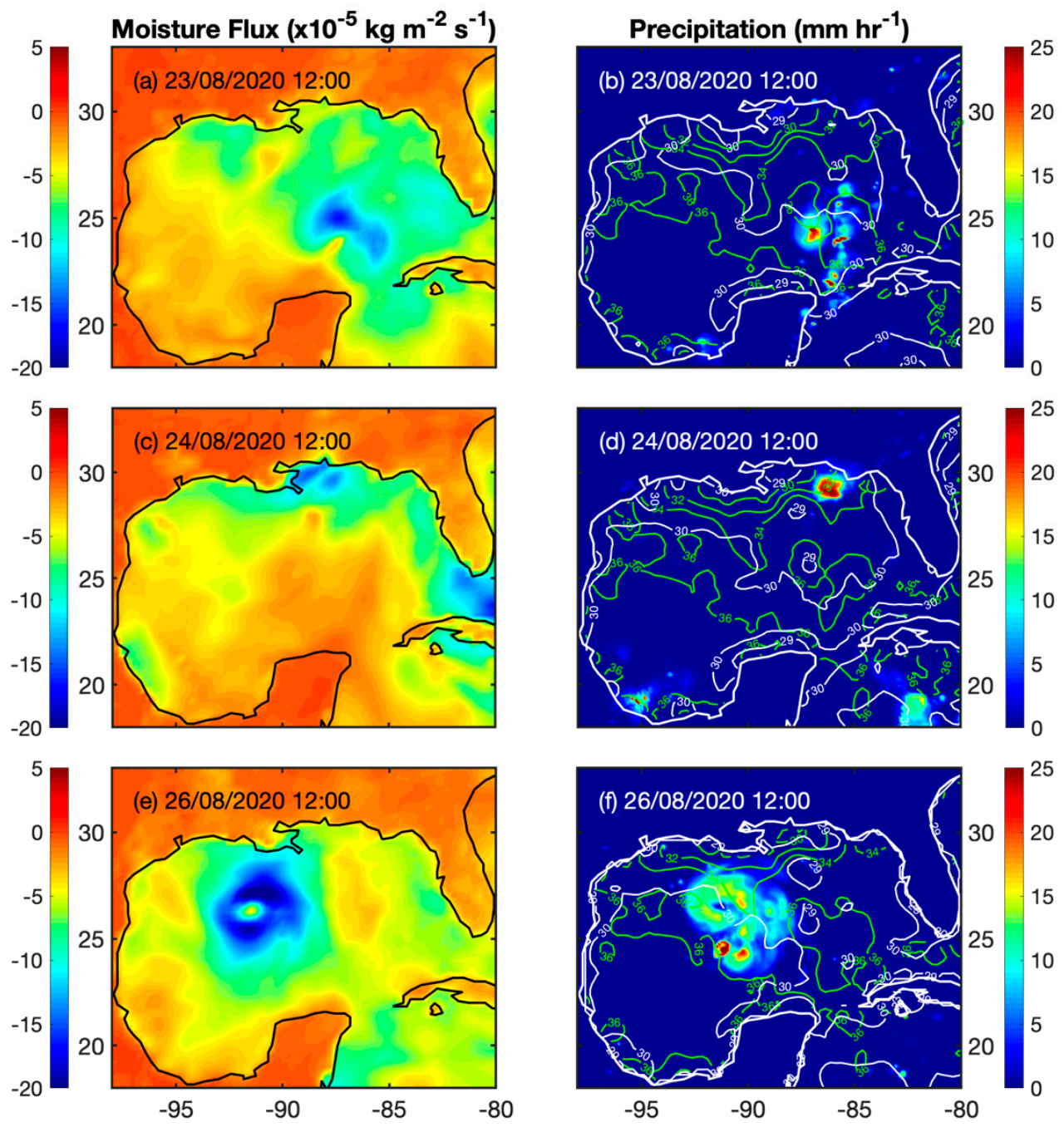

Figure 4. (a,c,e) Moisture flux $\left(\times 10^{-5} \mathrm{~kg} \mathrm{~m}^{-2} \mathrm{~s}^{-1}\right)$, and $(\mathbf{b}, \mathbf{d}, \mathbf{f})$ global precipitation measurement $\left(\mathrm{GPM} ; \mathrm{mm} \mathrm{hr}^{-1}\right.$ ) 30-min precipitation. Contours on (b,d,f) are sea surface salinity (SSS; psu) (green contours) and sea surface temperature (SST; ${ }^{\circ} \mathrm{C}$ ) (white contours).

\subsection{Enthalpy and Air-Sea Interactions}

OHC decreases most intensely within the preexisting CCE in the southeastern basin (Figure 5); the LC is characterized by a high OHC of approximately $10.4 \times 10^{-9} \mathrm{~J} \mathrm{~m}^{-2}$ and a deeper MLD of approximately $17 \mathrm{~m}$ entering through the Yucatán Channel, and the CCE has an OHC of approximately $9.5 \times 10^{-9} \mathrm{~J} \mathrm{~m}^{-2}$ centered about $26^{\circ} \mathrm{N}$ and $87^{\circ} \mathrm{W}$ (Figure $5 \mathrm{~g}$, ) ). $\mathrm{OHC}$ is generally depleted underneath both hurricane tracks, attributed to the loss of heat via evaporation seen in negative moisture flux signals (Figure $5 \mathrm{~g}-\mathrm{i}$ ). Laura's track aligns with the OHC boundary found between higher OHC waters of WCEs in the western GoM (OHC of $10.3 \times 10^{-9} \mathrm{~J} \mathrm{~m}^{-2}$ to values exceeding $10.5 \times 10^{-9} \mathrm{~J} \mathrm{~m}^{-2}$; Figure $5 \mathrm{~g}-\mathrm{i}$ ) and lower OHC waters of the CCE (OHC of $9.5 \times 10^{-9} \mathrm{~J} \mathrm{~m}^{-2}$ to $10.0 \times 10^{-9} \mathrm{~J} \mathrm{~m}^{-2}$; Figure $\left.5 \mathrm{~g}-\mathrm{i}\right)$ in the eastern GoM; this was not crucial, but beneficial, to Laura's period of rapid intensification. After the passage of Marco, a minor deepening of the MLD is observed underneath the storm's track (Figure 5k). In general, both hurricanes mildly increased the MLD below their tracks over the GoM; Marco impacted the eastern half of the basin while Laura impacted the western half of the basin. 

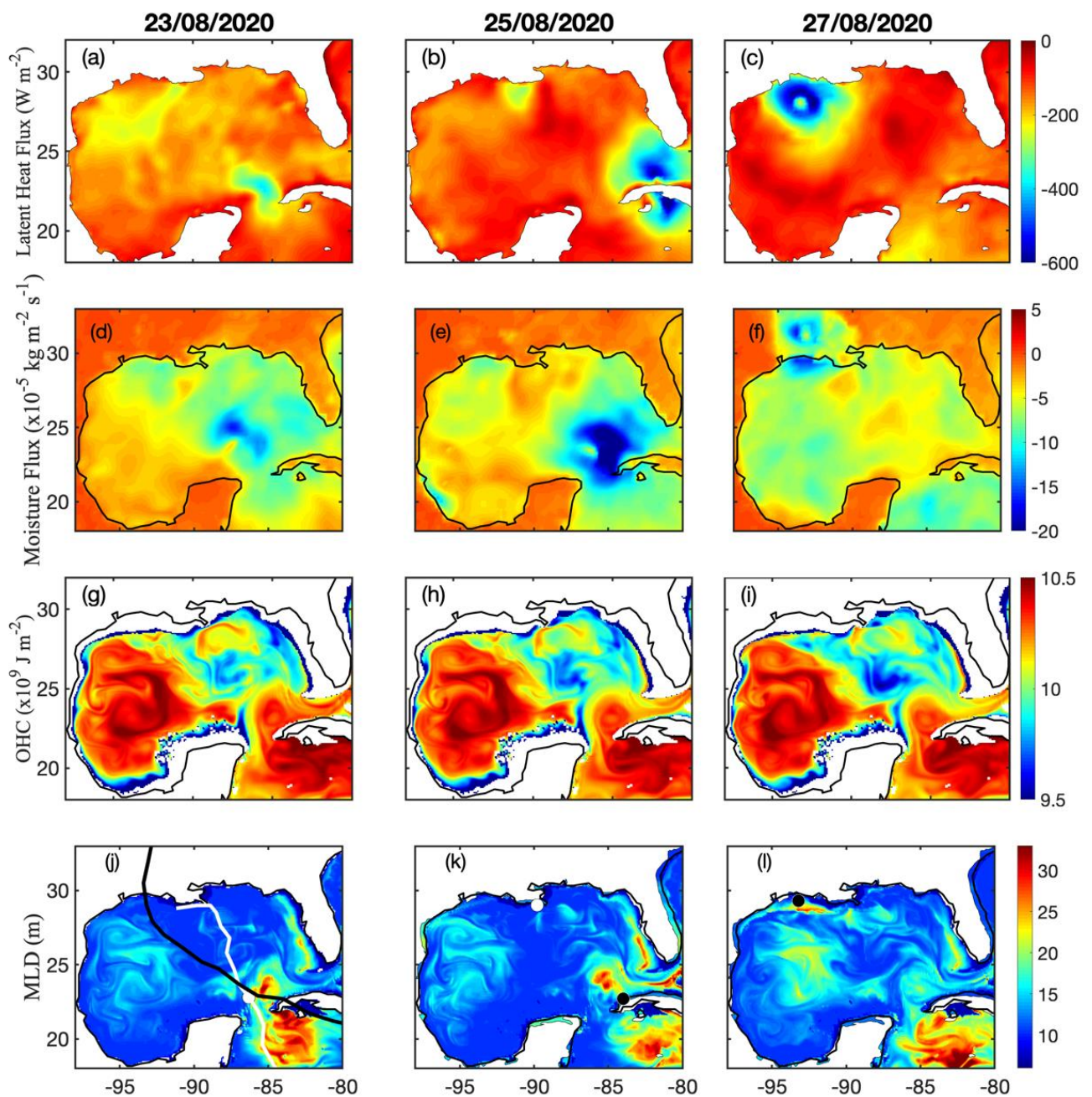

Figure 5. (a-c) Latent heat flux $\left(\mathrm{W} \mathrm{m}^{-2}\right)$ at time 00:00, (d-f) moisture flux $\left(\times 10^{-5} \mathrm{~kg} \mathrm{~m}^{-2} \mathrm{~s}^{-1}\right)$, $(\mathrm{g}-\mathbf{i})$ ocean heat content $\left(\times 10^{9} \mathrm{OHC} ; \mathrm{J} \mathrm{m}^{-2}\right)$, and $(\mathrm{j}-\mathbf{l})$ mixed layer depth (MLD; $\left.\mathrm{m}\right)$. The hurricane tracks $($ Marco $=$ white, Laura $=$ black) are depicted on plot $(j)$, and the positions of the hurricanes on the specific day are depicted by white and black dots on panels $(\mathbf{j}-\mathbf{l})$.

The greatest negative moisture flux values are centered over the storms with values approximately near $-2 \times 10^{-4} \mathrm{~kg} \mathrm{~m}^{-2} \mathrm{~s}^{-1}$ (maximum absolute values of $2.45 \times 10^{-5} \mathrm{~kg} \mathrm{~m}^{-2} \mathrm{~s}^{-1}$ (Marco) and $2.29 \times 10^{-4} \mathrm{~kg} \mathrm{~m}^{-2} \mathrm{~s}^{-1}$ (Laura)) due to the transfer of latent heat, or heat released through evaporation, that fueled the overlying storms (Figure $5 \mathrm{~d}-\mathrm{f}$ ). Latent heat flux and moisture flux behave similarly for both Marco and Laura (Figure 5). Latent heat flux values are -200 to $-300 \mathrm{~W} \mathrm{~m}^{-2}$ at both storms' outskirts, and maximum magnitudes of $-408.80 \mathrm{~W} \mathrm{~m}^{-2}$ (Marco) and $-699.32 \mathrm{~W} \mathrm{~m}^{-2}$ (Laura) are reported. Latent heat flux lags moisture flux in its position, which is further discussed in Section 4.

Vertical wind shear conditions were favorable for the weakening of Marco and the rapid intensification of Laura (Figure 6). Marco's ability to become cyclonically organized was interrupted by a peak in the environmental wind shear as the magnitude increased from 21 August until 22 August reaching a maximum of $27.32 \mathrm{~m} \mathrm{~s}^{-1}$ (Figure 6b). Moderate to minimum values of wind shear failed to hinder the intensification of Laura and allowed for the organization of deep atmospheric convection. A minimum magnitude of wind shear $\left(2.89 \mathrm{~m} \mathrm{~s}^{-1}\right)$ is observed upon Laura's entrance into the basin on 25 August to $26 \mathrm{Au}$ gust (Figure $6 \mathrm{~b}$ ). The zonal and meridional values generally reflect the variability of the magnitude of wind shear. Both zonal and meridional wind shear dip below zero and obtain negative values indicative of a weakening of vertical wind shear; this is discussed with greater detail in Section 4. Marco's period of weakening and Laura's subsequent period 
of rapid intensification are directly related to the instantaneous atmospheric conditions including environmental wind shear magnitude and direction.

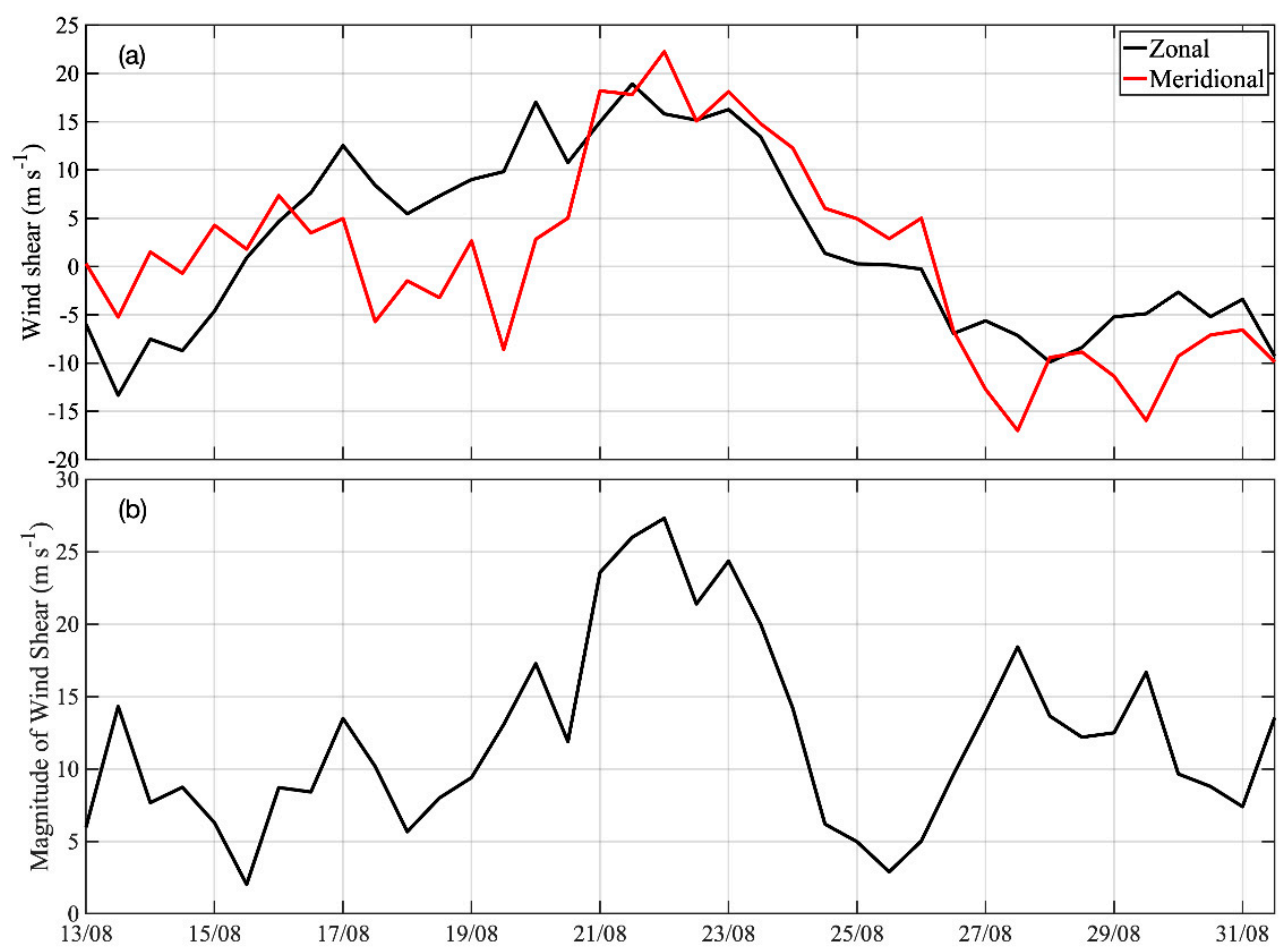

Figure 6. Environmental wind shear $\left(\mathrm{m} \mathrm{s}^{-1}\right)$ over $23-27^{\circ} \mathrm{N}$ and $87-93^{\circ} \mathrm{W}$ using $200 \mathrm{hPa}$ and $850 \mathrm{hPa}$ upper-level winds. (a) Shows both meridional and zonal environmental wind shear, and (b) shows the magnitude of the total environmental wind shear over time.

\subsection{Loop Current Interactions}

The interactions between the LC, LCEs and storms Marco and Laura are observed using SLA (Figure 7) and evaluating the location of WCEs and CCEs relative to each storm track (Figure 1). CCEs are recognized by a negative SLA (denoted by dashed lines in all figures that include SLA); characterized by cyclonic rotation, lower $\mathrm{OHC}$, and divergent outflow that promotes the upwelling of cooler subsurface waters. Most importantly for this study, there is a large CCE in the eastern GoM near the Yucatán Channel (centered at $26^{\circ} \mathrm{N}$ and $87^{\circ} \mathrm{W}$ ). Marco's track traverses the entire CCE along its major axis, maximizing its interactions with the GoM's cooler surface waters and lowest $\mathrm{OHC}$ waters (OHC of $9.5 \times 10^{-9} \mathrm{~J} \mathrm{~m}^{-2}$ to $10.0 \times 10^{-9} \mathrm{~J} \mathrm{~m}^{-2}$; Figure $5 \mathrm{~g}-\mathrm{i}$ ). Laura has modest interaction with the CCE; the high-pressure system shifting its track west allowed for the quick translation across the minor, southern axis of the CCE.

\subsection{Biophysical Ocean Dynamics}

Biophysical impacts from the passage of both storms are noted in sea surface signatures of SST cooling, an increase in SSS, and Chl-a concentration enhancement (Figure 7). Cold wake SST signatures are observed along the storm tracks. 22 August (Figure 7a) shows the state of the basin before the passage of either storm; temperatures along the storm tracks consistently exceed $29^{\circ} \mathrm{C}$. After the passage of Marco (Figure 7b), SST values, although decreasing along the track, remained above $26^{\circ} \mathrm{C}$ and thus did not impede Laura's chances for intensification. Laura's impacts expand and enhance the sea surface area covered by cooler SSTs when combined with Marco's cold wake for a maximum cooling of $1.9^{\circ} \mathrm{C}$ (Figure 7d). 

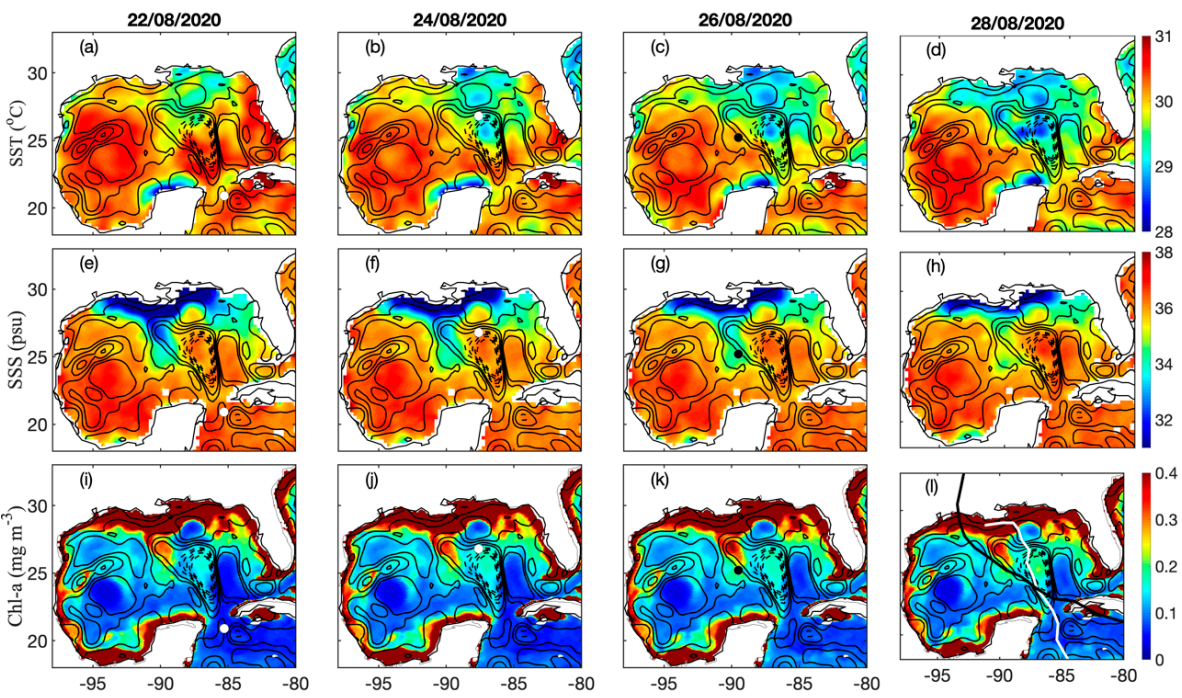

Figure 7. (a-d) Sea surface temperature (SST; $\left.{ }^{\circ} \mathrm{C}\right),(\mathbf{e}-\mathbf{h})$ sea surface salinity (SSS; psu), and (i-l) chlorophyll-a concentration (Chl-a; $\mathrm{mg} \mathrm{m}^{-3}$ ) shown before (22 August 2020), during Marco's near-peak intensity (24 August 2020), during Laura's near-peak intensity (26 August 2020) and after (28 August 2020). The hurricane tracks (Marco = white, Laura = black) are depicted on plot (1), and the positions of the hurricanes on the specific day are depicted by white and black dots when the latitudes and longitudes of the tracks permitted. Sea level anomaly (SLA; m) contours for each respective date; solid (dashed) contours are positive (negative) anomalies.

SSS increases are most notable within the CCE and the surface waters influenced by the surface freshwater plume of the MS River (Figure 7e-h). SSS increases from approximately $36 \mathrm{psu}$ to $37 \mathrm{psu}$ within the CCE (Figure $7 \mathrm{~h}$ ). Surface waters of the MS River plume become more saline and increase from approximately 32 psu to $35 \mathrm{psu}$ (Figure 7e,h). The greatest increase in SSS is observed over the reach of the fresher surface waters of the MS River output.

A minimal increase in Chl-a concentration is observed over the course of 6 days (a maximum increase of $0.1 \mathrm{mg} \mathrm{m}^{-3}$ ); the area of greatest increase is observed within the CCE (Figure 7i-1). The regions with pre-existing relatively high surface concentrations of Chl-a experience an enhancement of Chl-a and this implies an increase in phytoplankton productivity from the normal-state oligotrophic basin (Figure 7k).

The area of the MS River's surface freshwater discharge and the adjacent eastern coastal region underwent an increase of 2 psu or more when the difference between SSS on 21 August and 30 August is considered (Figure 8). SSS decreased in the southern and eastern regions of the basin (Figure 8f). Chl-a concentration is enhanced over the majority of the GoM, with values between $0 \mathrm{mg} \mathrm{m}^{-3}$ and up to $0.2 \mathrm{mg} \mathrm{m}^{-3}$ (Figure $8 \mathrm{a}-\mathrm{c}$ ). There is a noteworthy decrease in Chl-a concentration in the immediate coastal area of the MS River's surface outflow plume; this decrease is recorded with values greater than a $0.2 \mathrm{mg} \mathrm{m}^{-3}$ decrease in Chl-a concentration (Figure 8c).

The NEMO ocean model simulations permit the analysis of the subsurface response of the basin to the passages of the storms (Figure 9). This fixed point was chosen because it is where Marco was located at its maximum intensity, and Laura passed over $25^{\circ} \mathrm{N}$ and $85^{\circ} \mathrm{W}$, but not at its peak intensity. Lifting of the 36.5 psu halocline to a depth of approximately $60 \mathrm{~m}$ is observed (Figure $9 \mathrm{a}$ ). A freshening of $0.3 \mathrm{psu}$ of surface waters to an approximate depth of $20 \mathrm{~m}$ is shown in the SSS signal attributed to storm-associated precipitation. Precipitation is modeled as a modulating hurricane-force at the fixed point $25^{\circ} \mathrm{N}, 85^{\circ} \mathrm{W}$; however, precipitation has a lesser impact based on the surface interpretation in the northern basin (Figure 7h; Figure 8f). Upwelling of the $100 \mathrm{~m}$ and deeper halocline to depths of $60-80 \mathrm{~m}$ after the passage of the hurricanes is observed. The subsurface temperature response (Figure 9 b) is attributed to upwelling forced by hurricane winds. 

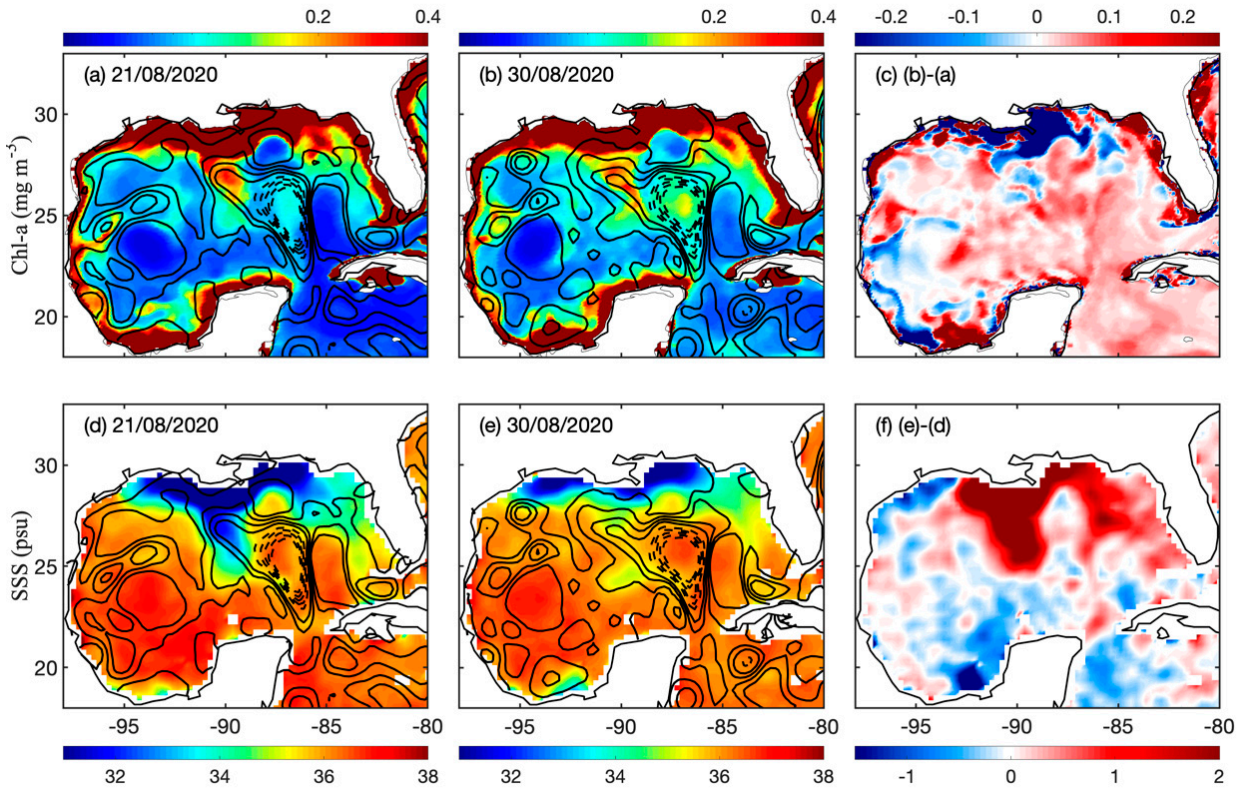

Figure 8. $(\mathbf{a}-\mathbf{c})$ The difference between chlorophyll-a concentration $\left(\mathrm{Chl}-\mathrm{a} ; \mathrm{mg} \mathrm{m}^{-3}\right)$ and $(\mathbf{d}-\mathbf{f})$ sea surface salinity (SSS; psu) from 21 August 2020 to 30 August 2020. Sea level anomaly (SLA; m) contours on each respective date; solid (dashed) contours are positive (negative) anomalies.

An increase in the BLT reduces the potential for SST cooling because the further the ILD is from the MLD, the more time and momentum are needed for the entrainment of cooler subsurface waters into the mixed layer. The BLT increases over the course of the storms' passing through the basin at the chosen fixed point (Figure 9a,b). An increase in the BLT after the passage of Marco confirms that there is an increase or maintenance of enthalpy and moisture fluxes further priming the GoM for Laura's rapid intensification as the storm traversed the basin.

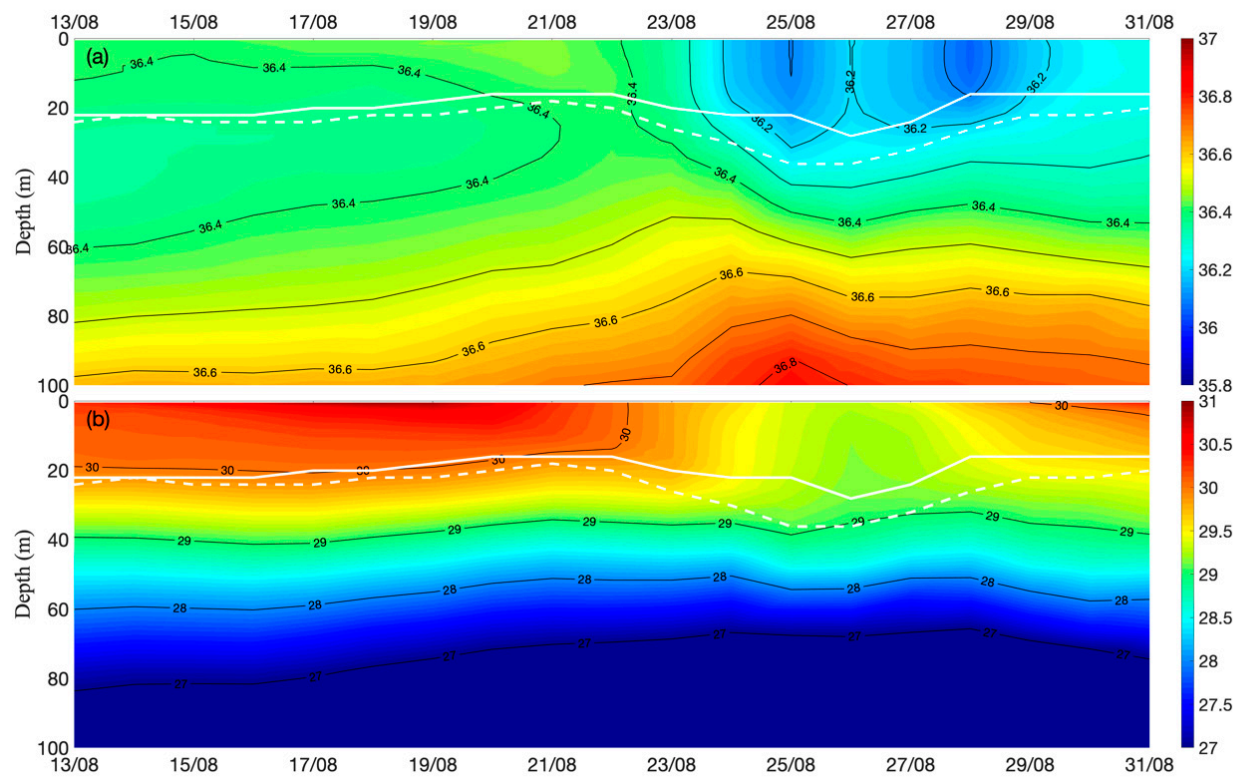

Figure 9. Depth-time taken at $25^{\circ} \mathrm{N}, 85^{\circ} \mathrm{W}$ of NEMO simulations (a) salinity (psu), and (b) temperature $\left({ }^{\circ} \mathrm{C}\right)$. The dashed white line is the isothermal layer depth (ILD; $\left.\mathrm{m}\right)$, the solid white line is the mixed layer depth (MLD; $\mathrm{m}$ ), and the area between the ILD and MLD represents the barrier layer thickness (BLT; m). 
Two fixed points are considered $\left(25^{\circ} \mathrm{N}\right.$ and $87^{\circ} \mathrm{W}$ (Marco) and $27^{\circ} \mathrm{N}$ and $92^{\circ} \mathrm{W}$ (Laura)) to study the cross-correlations between hurricane forcing mechanisms and resulting biophysical modulations as a function of the time separating the two variables; correlations at a lag of zero days are equal to 1.0 (Figure 10). SSS and SST were negatively related, with a correlation coefficient of -0.8 and a lead (SSS) lag (SST) trend of only 1-2 days (Figure 10b,d). Wind and SST relationships, for both hurricanes, had approximately a -0.8 correlation, indicating that hurricane winds directly drove SST response (Figure 10a,b). SST lagged approximately 1 day behind wind forcing for Marco; SST appeared to have almost no lag time for Laura's hurricane wind forcing (Figure 10a,b). Wind and SSS for Hurricane Laura (Figure 10b) have a similar, but inverse, relationship to wind and SST for Hurricane Laura; a positive correlation coefficient of 0.9 is observed on day 0 (almost no lag). Wind has the greatest similarities with a shift in time SST response for both storms.
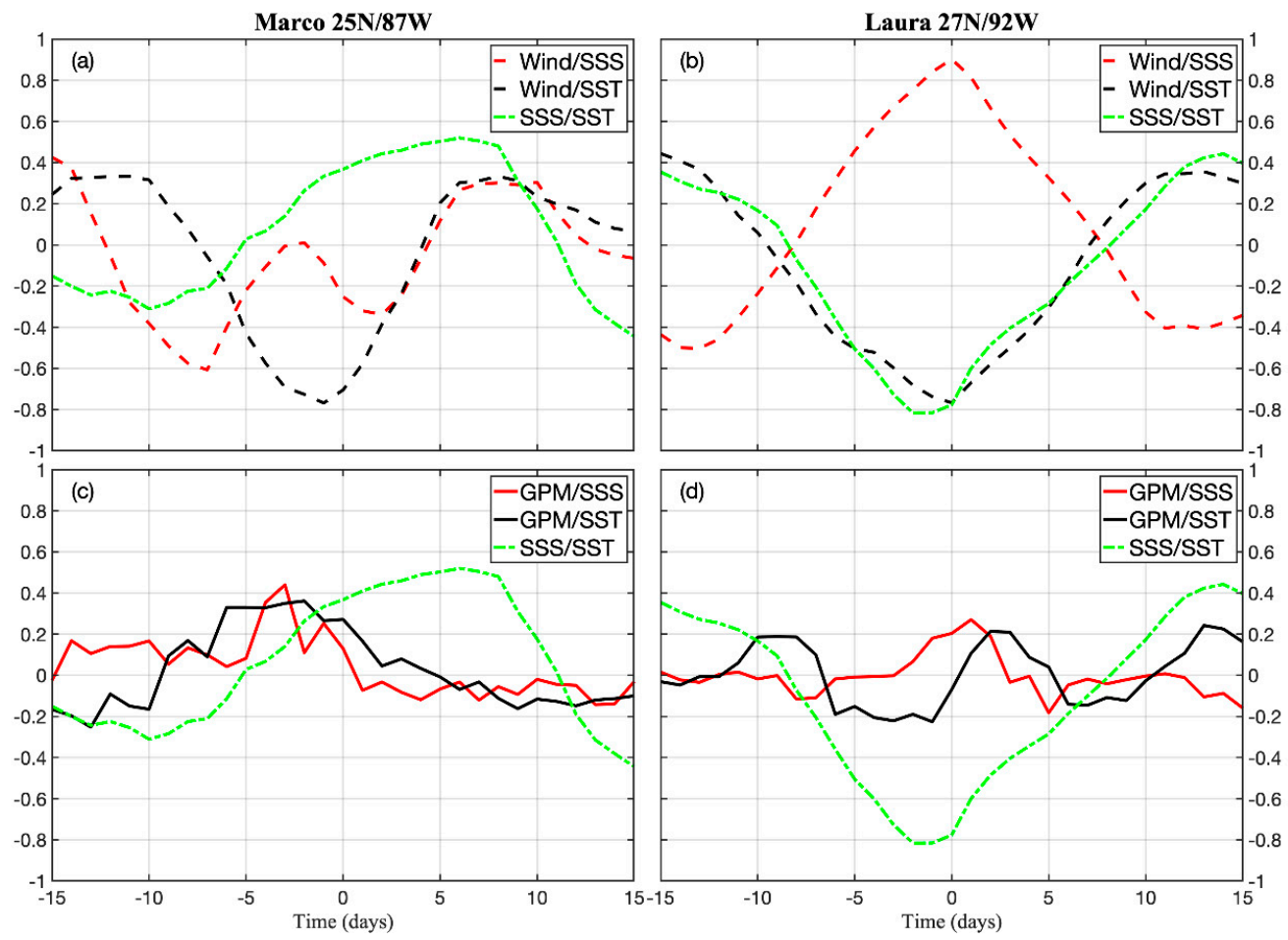

Figure 10. (a,c) Cross-correlation at fixed point $25^{\circ} \mathrm{N}$ and $87^{\circ} \mathrm{W}$, and (b,d) at fixed point $27^{\circ} \mathrm{N}$ and $92^{\circ} \mathrm{W}$. The sequence is normalized so the correlations at zero lag are identically 1.0. Encompassing data from dates 13 August 2020 to 04 September 2020. The first parameter leads the second parameter.

GPM precipitation measurements are minimally, but positively, related to SST and SSS response (Figure 10c,d). Overall, the greatest similarities are observed in the case of Hurricane Laura's wind/SSS, wind/SST and SSS/SST responses (Figure 10b); this indicates strong and organized hurricane convection and forcing winds. Marco generally has lower correlation coefficients between parameters characteristic of a weaker, less organized hurricane. GPM and its respective correlations with both SSS and SST for both storms had a less significant impact on ocean surface modulation at the reported fixed points than the hurricane winds (Figure 10c,d). All correlation results are statistically significant at a 99\% confidence level.

\section{Discussion and Conclusions}

Marco's existence in the GoM days prior to and during Laura's lifespan did not negatively impact conditions for Laura's period of rapid intensification from a Category 1 to a Category 4 hurricane within approximately $27 \mathrm{~h}$. Typically, it could be expected that Marco, or the occurrence of any tropical storm, would hinder the formation, maintenance 
and/or intensification of a consecutive cyclone in the same region. Marco was expected to monopolize the GoM's high $\mathrm{OHC}$, but instead made a very small dent in the reservoir that exists in the GoM. Marco's period of weakening is partially attributed to both increases in the magnitude of environmental wind shear and extensive interactions with the LC's CCE's lower OHC waters. Laura's period of rapid intensification was viable due to its minimal interactions with the CCE's lower OHC waters and its track being over high-OHC waters contained within WCEs, and common GoM water in the western basin. Additionally, the magnitude of environmental wind shear was minimized, allowing for uninterrupted deep organized atmospheric convection. The increases and decreases in wind shear are explained by variability in the zonal and meridional wind shears; most importantly, the upper-level zonal winds mostly control the vertical wind shear [43]. When zonal winds are negative, this is indicative of easterly flow in the upper atmosphere and a decrease in the vertical wind shear [43]. Additionally, the GoM's innate stable stratification assisted in maintaining heat and moisture fluxes at the air-sea interface after the passage of Marco was seen in the thickening of the BLT. Marco appears to have had little impact on Laura's lifespan attributed to the innate thermodynamic and circulation characteristics of the GoM that are ideal for energizing hurricanes.

The depletion of $\mathrm{OHC}$ is attributed to the loss of ocean enthalpy to the atmosphere via moisture fluxes [8,44]; however, the $\mathrm{OHC}$ throughout the basin does not drop below or even approach a value close to $6.0 \times 10^{-8} \mathrm{~J} \mathrm{~m}^{-2}$, the accepted minimum $\mathrm{OHC}$ value needed for hurricane intensification [8]. A decrease in $\mathrm{OHC}$ indicates the cooling of the MLD due to vertical mixing attributed to wind stress upon the upper ocean, establishing mixing across the base of the MLD [45]. Moisture and heat fluxes are critical to observe when predicting hurricane intensity change and directly reflect the value of OHC $[8,44]$. The similar behavior and negative values of both fluxes are attributed to thermodynamic disequilibrium of the air-sea interface, where warm moisture from the basin surface is evaporated to the atmosphere and fuels the overlying cyclones [44]. The latent heat flux signal lags moisture flux due to a change in the number or types of assimilated data; changes in the assimilated data can lead to stilted trends or false variability between reanalysis parameters and even local scale observations.

The MLD, as determined by NEMO, is relatively shallow in the majority of the basin (less than $20 \mathrm{~m}$ ); the thinner the MLD is, the more susceptible the region is to surface cooling by wind-induced upwelling [46,47]. More importantly, the mixed layer and atmosphere contrast determines the net surface heat flux from ocean to atmosphere [47]. Hurricane winds deepen the mixed layer through shear-induced mixing and there appears to be a lag time in the oceanic response $[9,45]$. A minimal increase in the MLD is attributed to translation speeds of each storm; when a storm is slower it has more time to insert momentum into the upper layer, thus increasing the vertical shear at the mixed layer base and thus a more effective deepening of the MLD [45,48]. Both storms quickly moved across the basin, Marco at $5.67 \mathrm{~m} \mathrm{~s}^{-1}$ and Laura at $7.02 \mathrm{~m} \mathrm{~s}^{-1}$, and the slower storm, Marco, was much less intense. The relatively deeper values of MLD are located east of the storm track attributed to the rightward bias that is further discussed below.

Decreased SST and an increase in the depth of the mixed layer are dominated by windinduced vertical mixing and entrainment and are observed along both hurricane tracks. The asymmetry of SST and MLD response, characterized by a rightward bias, to Hurricane Laura is attributed to the asymmetry in the wind stress vectors' turning direction (clockwise (anticlockwise) on the right (left) side of the track); this bias is observed in both the MLD velocity and resulting entrainment $[18,45,48]$. The SST signature is heavily dependent upon the strength and translation speed of hurricanes; a powerful, quick moving hurricane will exhibit a stronger rightward bias and limited upwelling-induced SST response, while a slower hurricane of the same intensity will encourage more upwelling, significantly enhancing the SST response $[45,48]$. Laura's cold wake appearing to the right of the hurricane track is attributed to a quick translation speed and strong hurricane winds. 
Marco's slower translation speed compensates for its lower intensity, allowing more time over a fixed point for the storm to input momentum into the upper ocean.

Chl-a concentrations serve as a proxy for phytoplankton biomass and are used to evaluate the biological response of the upper oceans to the passage of a tropical cyclone, or multiple cyclones [4]. Marco is responsible for the initiation of Chl-a concentration enhancement. Laura contributes to the longevity of the production, supplementing some nutrients by vertical mixing that extended the occurrence of the phytoplankton blooms. However, it is difficult to distinguish how much of the biophysical modulations each hurricane was responsible for. The translation speed of a storm and the storm intensity have direct implications for the magnitude of the impacts it will have upon the underlying ocean [48]. There is an enhancement of Chl-a over a majority of the GoM's surface waters alluding to wind-induced upwelling. The enhancement of Chl-a is not as instantaneous as the decrease in SST due to a lag time of biological productivity appearing along hurricane tracks. The upwelling of nutrients, alongside the upwelling of cooler waters, is not shown on the spatial map and it takes time to see a visual increase in Chl-a concentration due to the processing time of phytoplankton's consumption of nutrients.

The region of the MS River freshwater lens is an area of interest when observing SSS and Chl-a hurricane-forced modulations. In this surface plume region, there is an increase in SSS and a decrease in Chl-a concentrations three days after hurricane Laura's landfall (30 August). The increase in SSS is attributed to strong upwelling in this region, while the decrease in Chl-a is attributed to the difference in nutrient content of the upwelled subsurface basin waters and the MS River output waters. The MS River expels high nutrient content waters that support biological productivity at the mouth of the river. The upwelled waters are of lower nutrient contents than the waters coming straight from the river, leading to a decrease in Chl-a concentrations or biological productivity.

The areas of greatest biophysical impacts are observed within the preexisting CCE and the MS River freshwater surface plume (Figure 7; Figure 8). It has been noted that within CCE impacts of tropical cyclones, specifically SST response, the deepening of the MLD and SSS response are enhanced [4,18-20]. Ekman pumping of higher salinity waters to the surface explains the observed increase in SSS. Additionally, entrainment, or vertical mixing, is accepted as the dominant physical mechanism in SST response to a hurricane $[4,45]$. The modulations of the MS River surface region are aforenoted. Marco initialized a change in the basin while Laura then increased the spatial reach and the temporal duration of the hurricane-induced modulations.

When considering Figure 9, precipitation has a greater impact on the chosen fixed point than precipitation does in the northern basin. The greater input of rainfall and the freshening of the surface waters at $25^{\circ} \mathrm{N}, 85^{\circ} \mathrm{W}$ is attributed to the compounded rainfall of both hurricanes. The only point of intersection for Hurricanes Laura and Marco is approximately $25^{\circ} \mathrm{N}, 85^{\circ} \mathrm{W}$ and thus explains the surface freshening and freshening of waters up to $30 \mathrm{~m}$ depth observed at this point. Furthermore, the lack of surface freshening in the northern basin can be attributed to the departure of Hurricane Marco's and Hurricane Laura's tracks, thus a lack of compounding precipitation. Upwelling outweighs rainfall in the northern basin. Precipitation that accompanies the hurricanes had little apparent impact on the SSS of the northern GoM when observing SMAP v5 data, for lack of surface freshening observed at the ocean surface (Figure 7h; Figure 8f).

The GoM has a barrier layer due to its strongly stratified halocline (influenced by the freshwater flux of the MS River) within its deeper isothermal layer [40]. The role of the BLT on air-sea interactions is important to consider because upper-ocean dynamics directly influence the resulting storm intensity [49]. As Marco and Laura pass over the basin, SST cooling is reduced due to the stratification and stability of the water column [50]. Balaguru et al. (2012) found that a reduction in vertical mixing increases the heat fluxes from the ocean to the atmosphere, allowing for the intensification of overlying tropical cyclones [50]. Rudzin et al. (2018) agree with the aforenoted study and conclude that a reduction in hurricane-wind-induced ocean mixing reduces associated SST cooling, and 
heat and moisture fluxes to the atmosphere are sustained [49]. In the GoM, further analysis of the barrier layer is required in relation to hurricane interactions.

Author Contributions: Conceptualization, B.S.; methodology, E.N.E. and C.B.T.; software, E.N.E. and C.B.T.; validation, C.B.T. and E.N.E.; formal analysis, E.N.E., B.S., and C.B.T.; investigation, E.N.E., B.S., and C.B.T.; resources, B.S.; data curation, E.N.E. and C.B.T.; writing, E.N.E., C.B.T., and B.S.; visualization, E.N.E., B.S., and C.B.T.; supervision, B.S.; funding acquisition, B.S. All authors have read and agreed to the published version of the manuscript.

Funding: This research was funded by the NASA/South Carolina Space Grant Consortium MiniREAP grant awarded to B.S.

Institutional Review Board Statement: This is NRL contribution number \#JA-7320-21-5169. It is approved for public release, distribution is unlimited.

Informed Consent Statement: Not applicable.

Data Availability Statement: The track and evolution data used are provided by NOAA's National Hurricane Center hurricane advisory archives (https:/ / www.nhc.noaa.gov/archive/2020/MARCO. shtml, https:/ / www.nhc.noaa.gov/archive/2020/LAURA.shtml) accessed on 13 November 2020. ASCATv2.1 daily winds were obtained from RSS (http://www.remss.com/missions/ascat/) accessed on 8 February 2021. CCMPv2.0 winds were obtained from RSS (http:// data.remss.com/ ccmp/v02.0.NRT/Y2020/M08/) accessed on 29 April 2021. AVHRR OISST SST data were retrieved from NOAA's Earth System Research Laboratory (https:/ / www.ncdc.noaa.gov / oisst) accessed on 4 December 2020. SMAPv5 SSS data are a product of NASA's Jet Propulsion Lab (JPL) and provided by JPL (https:/ / podaac-opendap.jpl.nasa.gov / opendap/hyrax/allData/smap/ contents.html) accessed on 4 December 2020. ECMWF ERA5 atmospheric data are available at https://www.ecmwf.int/en/forecasts/datasets accessed on 11 January 2021, 19 February 2021, and 29 April 2021. Daily ocean color data are retrieved from NOAA's Coastwatch data portal (https:/ / coastwatch.noaa.gov/cw/satellite-data-products/ocean-color/near-real-time/viirsmulti-sensor-gap-filled-chlorophyll-dineof.html) accessed on 9 December 2020. GPM 30-min and daily data from NASA/JAXA's mission were obtained through NASA's Earthdata database (https: //pmm.nasa.gov/data-access/downloads/gpm) accessed on 13 January 2021. OLR product is developed from NOAA's National Center for Environmental Prediction and distributed by NOAA's Physical Research laboratory (https://psl.noaa.gov/data/gridded/data.interp_OLR.html) accessed on 2 December 2020. Daily SLA were obtained from Copernicus Marine and Environmental Monitoring Service (ma-rine.copernicus.eu) accessed on 11 December 2020. NEMO model simulations are available from Copernicus (http:/ / marine.copernicus.eu/services-portfolio/access-to-products/?option= com_csw\&amp;view=details\&amp;product_id=GLOBAL_ANALYSIS_FORECAST_PHY_001_024) accessed on 10 February 2021.

Acknowledgments: We are thankful for the helpful comments of the four anonymous reviewers which improved the quality of this paper.

Conflicts of Interest: The authors declare no conflict of interest.

\section{References}

1. Jaimes, B.; Shay, L.K.; Uhlhorn, E.; Cook, T.M.; Brewster, J.; Halliwell, G.; Black, P.G. Influence of loop current ocean heat content on Hurricanes Katrina, Rita, and Wilma. In Proceedings of the 27th Conference on Hurricanes and Tropical Meteorology, Monterey, CA, USA, 24-28 April 2006.

2. Prasad, T.G.; Hogan, P.J. Upper-ocean response to Hurricane Ivan in a $1 / 25^{\circ}$ nested Gulf of Mexico HYCOM. J. Geophys. Res. Space Phys. 2007, 112, 04013. [CrossRef]

3. Leipper, D.F.; Volgenau, D. Hurricane Heat Potential of the Gulf of Mexico. J. Phys. Oceanogr. 1972, 2, 218-224. [CrossRef]

4. Gierach, M.M.; Subrahmanyam, B. Biophysical responses of the upper ocean to major Gulf of Mexico hurricanes in 2005. J. Geophys. Res. Space Phys. 2008, 113, 04029. [CrossRef]

5. Gierach, M.M.; Subrahmanyam, B. Satellite Data Analysis of the Upper Ocean Response to Hurricanes Katrina and Rita (2005) in the Gulf of Mexico. IEEE Geosci. Remote. Sens. Lett. 2007, 4, 132-136. [CrossRef]

6. Blake, E.S. The 2017 Atlantic Hurricane Season: Catastrophic Losses and Costs. Weatherwise 2018, 71, 28-37. [CrossRef]

7. Vipulanandan, C.; Parameswaran, S. Hurricane Harvey Survey Assessment and Lessons Learned. Texas Hurricane Center for Innovative Technology Conference and Exhibition, 2018. Available online: http:/ /hurricane.egr.uh.edu/sites/hurricane.egr.uh. edu/files/files/2018/HURRICANE-HARVEY-SURVEY-ASSESSMENT.pdf (accessed on 14 March 2021). 
8. Mainelli, M.; DeMaria, M.; Shay, L.K.; Goni, G. Application of Oceanic Heat Content Estimation to Operational Forecasting of Recent Atlantic Category 5 Hurricanes. Weather Forecast. 2008, 23, 3-16. [CrossRef]

9. Morey, S.L.; Bourassa, M.A.; Dukhovskoy, D.S.; O’Brien, J.J. Modeling studies of the upper ocean response to a tropical cyclone. Ocean Dyn. 2006, 56, 594-606. [CrossRef]

10. Brokaw, R.J.; Subrahmanyam, B.; Morey, S.L. Loop Current and Eddy-Driven Salinity Variability in the Gulf of Mexico. Geophys. Res. Lett. 2019, 46, 5978-5986. [CrossRef]

11. Alvera-Azcárate, A.; Barth, A.; Weisberg, R.H. The Surface Circulation of the Caribbean Sea and the Gulf of Mexico as Inferred from Satellite Altimetry. J. Phys. Oceanogr. 2009, 39, 640-657. [CrossRef]

12. Le Hénaff, M.; Kourafalou, V.; Morel, Y.; Srinivasan, A. Simulating the dynamics and intensification of cyclonic Loop Current Frontal Eddies in the Gulf of Mexico. J. Geophys. Res. Space Phys. 2012, 117, C02034. [CrossRef]

13. Zavala-Hidalgo, J.; Morey, S.L.; O’Brien, J.J.; Zamuido, L. On the Loop Current Eddy shedding variability. Atmósfera 2005, 19, 41-48.

14. DeMaria, M.; Mainelli, M.; Shay, L.K.; Knaff, J.A.; Kaplan, J. Further Improvements to the Statistical Hurricane Intensity Prediction Scheme (SHIPS). Weather Forecast. 2005, 20, 531-543. [CrossRef]

15. Palmen, E. On the formation and structure of tropical hurricanes. Geophysica 1948, 3, $26-38$.

16. Hong, X.; Chang, S.W.; Raman, S.; Shay, L.K.; Hodur, R. The Interaction between Hurricane Opal (1995) and a Warm Core Ring in the Gulf of Mexico. Mon. Weather Rev. 2000, 128, 1347-1365. [CrossRef]

17. Shay, L.K.; Goni, G.J.; Black, P.G. Effects of a warm oceanic feature on Hurricane Opal. Mon. Weather Rev. 2000, 128, 1366-1383. [CrossRef]

18. Walker, N.D.; Leben, R.R.; Balasubramanian, S. Hurricane-forced upwelling and chlorophyll a enhancement within cold-core cyclones in the Gulf of Mexico. Geophys. Res. Lett. 2005, 32, L18610. [CrossRef]

19. Huang, J.; Xu, F.; Zhou, K.; Xiu, P.; Lin, Y. Temporal evolution of near-surface chlorophyll over cyclonic eddy lifecycles in the southeastern Pacific. J. Geophys. Res. Oceans 2017, 122, 6165-6179. [CrossRef]

20. Hausmann, U.; McGillicuddy, D.J.; Marshall, J. Observed mesoscale eddy signatures in Southern Ocean surface mixed-layer depth. J. Geophys. Res. Oceans 2017, 122, 617-635. [CrossRef]

21. Willis, J.J.; Helms, T.A. Extended abstract: Welcome and opening remarks: Convention planning in a time of covid-19, negative oil prices, record hurricane season, and social unrest. GeoGulf Trans. 2020, 70, 345-347.

22. Oppenheimer, M. As the world burns: Climate change's dangerous next phase. Foreign Aff. 2020, 34, 34-41.

23. Rippey, B.; Thoman, R.; Stuefer, M.; Moore, B.; Grimes, J.; Hartl, L.; Halverson, J. Weatherwatch. Weatherwise 2021, $74,42-57$. [CrossRef]

24. Jafari, N.H.; Chen, Q.; Cadigan, J. Rapid deployment and post-storm reconnaissance of hurricane Laura. Coast. Eng. Proc. 2020, 36, 60. [CrossRef]

25. Larson, K.M.; Lay, T.; Yamazaki, Y.; Cheung, K.F.; Ye, L.; Williams, S.D.; Davis, J.L. Dynamic Sea Level Variation From GNSS: 2020 Shumagin Earthquake Tsunami Resonance and Hurricane Laura. Geophys. Res. Lett. 2021, 48. [CrossRef]

26. Ricciardulli, L.; Meissner, T.; Wentz, F. Towards a Climate Data Record of satellite ocean vector winds. In Proceedings of the 2012 IEEE International Geoscience and Remote Sensing Symposium, Munich, Germany, 22-27 July 2012; pp. $2067-2069$.

27. Figa-Saldaña, J.; Wilson, J.J.W.; Attema, E.; Gelsthorpe, R.; Drinkwater, M.R.; Stoffelen, A. The advanced scatterometer (ASCAT) on the meteorological operational (MetOp) platform: A follow on for European wind scatterometers. Can. J. Remote Sens. 2002, 28, 404-412. [CrossRef]

28. Reynolds, R.W.; Smith, T.M.; Liu, C.Y.; Chelton, D.B.; Casey, K.S.; Schlax, M.G. Daily High-Resolution-Blended Analyses for Sea Surface Temperature. J. Clim. 2007, 20, 5473-5496. [CrossRef]

29. Entekhabi, D.; Njoku, E.; O’Neill, P.; Spencer, M.; Jackson, T.; Entin, J.; Im, E.; Kellogg, K. The Soil Moisture Active/Passive Mission (SMAP). In Proceedings of the IGARSS 2008-2008 IEEE International Geoscience and Remote Sensing Symposium; Institute of Electrical and Electronics Engineers (IEEE), Boston, MA, USA, 6-11 July 2008; Volume 3, p. III-1.

30. Fore, A.G.; Yueh, S.H.; Tang, W.; Stiles, B.W.; Hayashi, A.K. Combined Active/Passive Retrievals of Ocean Vector Wind and Sea Surface Salinity With SMAP. IEEE Trans. Geosci. Remote. Sens. 2016, 54, 7396-7404. [CrossRef]

31. Bian, G.-F.; Nie, G.-Z.; Qiu, X. How well is outer tropical cyclone size represented in the ERA5 reanalysis dataset? Atmos. Res. 2020, 249, 105339. [CrossRef]

32. Hersbach, H.; Bell, B.; Berrisford, P.; Hirahara, S.; Horányi, A.; Muñoz-Sabater, J.; Nicolas, J.; Peubey, C.; Radu, R.; Schepers, D.; et al. The ERA5 global reanalysis. Q. J. R. Meteorol. Soc. 2020, 146, 1999-2049. [CrossRef]

33. Roman-Stork, H.L.; Subrahmanyam, B.; Murty, V.S.N. The Role of Salinity in the Southeastern Arabian Sea in Determining Monsoon Onset and Strength. J. Geophys. Res. Oceans 2020, 125. [CrossRef]

34. Liu, X.; Wang, M. Gap Filling of Missing Data for VIIRS Global Ocean Color Products Using the DINEOF Method. IEEE Trans. Geosci. Remote. Sens. 2018, 56, 4464-4476. [CrossRef]

35. Qi, L.; Hu, C.; Barnes, B.B.; Lee, Z. VIIRS captures phytoplankton vertical migration in the NE Gulf of Mexico. Harmful Algae 2017, 66, 40-46. [CrossRef]

36. Beckers, J.M.; Rixen, M. EOF Calculations and Data Filling from Incomplete Oceanographic Datasets. J. Atmos. Ocean. Technol. 2003, 20, 1839-1856. [CrossRef] 
37. Le Traon, P.Y.; Nadal, F.; Ducet, N. An Improved Mapping Method of Multisatellite Altimeter Data. J. Atmos. Ocean. Technol. 1998, 15, 522-534. [CrossRef]

38. Vidard, A.; Bouttier, P.-A.; Vigilant, F. NEMOTAM: Tangent and adjoint models for the ocean modelling platform NEMO. Geosci. Model Dev. 2015, 8, 1245-1257. [CrossRef]

39. Luo, H.; Bracco, A.; Cardona, Y.; McWilliams, J.C. Submesoscale circulation in the northern Gulf of Mexico: Surface processes and the impact of the freshwater river input. Ocean Model. 2016, 101, 68-82. [CrossRef]

40. Foltz, G.R.; McPhaden, M.J. Impact of Barrier Layer Thickness on SST in the Central Tropical North Atlantic. J. Clim. 2009, 22, 285-299. [CrossRef]

41. Emanuel, K.; DesAutels, C.; Holloway, C.; Korty, R. Environmental Control of Tropical Cyclone Intensity. J. Atmos. Sci. 2004, 61, 843-858. [CrossRef]

42. Zehr, R.M. Environmental Vertical Wind Shear with Hurricane Bertha (1996). Weather Forecast. 2003, 18, 345-356. [CrossRef]

43. Aiyyer, A.R.; Thorncroft, C. Climatology of Vertical Wind Shear over the Tropical Atlantic. J. Clim. 2006, 19, 2969-2983. [CrossRef]

44. Jaimes, B.; Shay, L.K.; Uhlhorn, E.W. Enthalpy and Momentum Fluxes during Hurricane Earl Relative to Underlying Ocean Features. Mon. Weather. Rev. 2015, 143, 111-131. [CrossRef]

45. Price, F.J. Upper ocean response to a hurricane. J. Phys. Oceanogr. 1981, 11, 153-175. [CrossRef]

46. Kara, A.B.; Rochford, P.A.; Hurlburt, H.E. Mixed layer depth variability over the global ocean. J. Geophys. Res. Space Phys. 2003, 108, 3079. [CrossRef]

47. Chen, D.; Busalacchi, A.J.; Rothstein, L.M. The roles of vertical mixing, solar radiation, and wind stress in a model simulation of the sea surface temperature seasonal cycle in the tropical Pacific Ocean. J. Geophys. Res. Space Phys. 1994, 99, 20345. [CrossRef]

48. Mei, W.; Pasquero, C.; Primeau, F. The effect of translation speed upon the intensity of tropical cyclones over the tropical ocean. Geophys. Res. Lett. 2012, 39, L07801. [CrossRef]

49. Rudzin, J.E.; Shay, L.K.; Johns, W.E. The Influence of the Barrier Layer on SST Response during Tropical Cyclone Wind Forcing Using Idealized Experiments. J. Phys. Oceanogr. 2018, 48, 1471-1478. [CrossRef]

50. Balaguru, K.; Chang, P.; Saravanan, R.; Leung, L.R.; Xu, Z.; Li, M.; Hsieh, J.-S. Ocean barrier layers' effect on tropical cyclone intensification. Proc. Natl. Acad. Sci. USA 2012, 109, 14343-14347. [CrossRef] [PubMed] 